\title{
Assessment of the shaping ability of three systems used in long oval canals
}

\author{
Avaliação da capacidade de modelagem de três sistemas utilizados em canais ovais longos \\ Evaluación de la capacidade de modelado de tres sistemas utilizados en canales ovalados largos
}

Received: 08/19/2021 | Reviewed: 08/26/2021 | Accept: 08/31/2021 | Published: 09/03/2021

Kauhanna Vianna de Oliveira

ORCID: https://orcid.org/0000-0001-5238-6986 Universidade Positivo, Brazil

E-mail: kauhanna@hotmail.com

Flávia Sens Fagundes Tomazinho

ORCID: https://orcid.org/0000-0001-5553-6943 Universidade Positivo, Brazil

E-mail: flavia.tomazinho@gmail.com

Vinícius Rodrigues dos Santos

ORCID: https://orcid.org/0000-0002-0369-3485

Universidade Estadual de Campinas, Brazil

E-mail: vinicius.santos91@hotmail.com

Wander José da Silva

ORCID: https://orcid.org/0000-0002-5613-5081

Universidade Estadual de Campinas, Brazil

E-mail: wanderjose@fop.unicamp.br

Prescila Mota de Oliveira Kublistki

ORCID: https://orcid.org/0000-0002-3828-2328 Universidade Positivo, Brazil

E-mail: prescilamota@hotmail.com

Marilisa Carneiro Leão Gabardo

ORCID: https://orcid.org/0000-0001-6832-8158

Universidade Positivo, Brazil

E-mail: marilisagabardo@gmail.com

Natanael Henrique Ribeiro Mattos

ORCID: https://orcid.org/0000-0003-2755-2270

Universidade Tuiutí do Paraná, Brazil

E-mail: natanael.mattos@utp.br

Flares Baratto-Filho

ORCID: https://orcid.org/0000-0002-5649-7234

Universidade da Região de Joinville, Brazil E-mail: fbaratto1@gmail.com

\begin{abstract}
The aim of this study was to analyze volume variation, untouched walls, transportation, and centralization in long oval canals prepared with ProTaper Next (PTN), X File (XF) and X Gray (XG) by microcomputed tomography (micro$\mathrm{CT}$ ). Forty-five lower incisors were divided into three groups (PTN, XF and XG) with 15 specimens each, according to the micro-CT pre-instrumentation (PI) analysis. After the use of each instrument new exams were performed. Volume variation and untouched walls data were analyzed by two-way ANOVA, and for the first one, Tukey HSD or Games-Howell tests were applied in the sequence; data of transportation and centralization were compared by Kruskal-Wallis and Mann-Whitney test. The statistical significance was set at $\mathrm{p}<0.05$. Between thirds, higher wear values were found in the cervical $(\mathrm{p}<0.001)$. PI and the instrument X3 $(30 / .07)$ differed in all systems $(\mathrm{p}<0.05)$. No significant difference concerning the percentage of untouched walls between the systems occurred $(p=0.836$ ), while the degree of transportation and centralization was similar between then, with $\mathrm{p}$ values of 0.531 and 0.155 , respectively. However, between thirds, significant difference was found $(\mathrm{pc}=0.029)$, with the middle third presenting superior centralization than the apical $(\mathrm{p}=0.010)$. In conclusion, PTN, XF and XG had similar results in the shaping ability, transportation, and centralization of long oval canals.
\end{abstract}

Keywords: Endodontics; Root canal preparation; X-Ray microtomography.

\section{Resumo}

O objetivo deste estudo foi analisar a variação de volume, paredes não tocadas, transporte e centralização em canais longo-ovais preparados com ProTaper Next (PTN), X File (XF) e X Gray (XG) por microtomografia computarizada (micro-CT). Quarenta e cinco incisivos inferiores foram divididos em três grupos (PTN, XF e XG) com 15 espécimes em cada, conforme a micro-CT pré-instrumenetação (PI). Após o uso de cada instrumento novos exames eram feitos. Os dados de variação de volume e de paredes não tocadas foram analisados pelo teste de ANOVA a dois fatores. e 
para o primeiro, os testes de Tukey HSD ou de Games-Howell foram aplicados na sequência. Os dados de transporte e centralização foram comparados por Kruskal-Wallis e Mann-Whitney. A significância estatística foi estabelecida em $\mathrm{p}<0,05$. Entre os terços, maiores valores de desgaste foram encontrados na cervical ( $\mathrm{p}<0,001)$. PI e o instrumento X3 $(30 / .07)$ diferiram em todos os sistemas $(\mathrm{p}<0,05)$. Não houve diferença significativa quanto ao percentual de paredes não tocadas entre os sistemas $(\mathrm{p}=0,836)$, enquanto o grau de transporte e centralização foi semelhante entre os mesmos, com valores de p de 0,531 e 0,155, respectivamente. Contudo, entre terços, diferença significativa foi encontrada ( $\mathrm{p}=0,029)$, com o terço médio apresentando centralização superior ao apical $(\mathrm{p}=0,010)$. Em conclusão, PTN, XF e XG tiveram resultados semelhantes na capacidade de modelagem, transporte e centralização de canais longo-ovais.

Palavras-chave: Endodontia; Preparo de canal radicular; Microtomografia por Raio-x.

\section{Resumen}

El objetivo de este estudio fue analizar la variación de volumen, paredes intactas, transporte y centrado en conductos ovalados largos preparados con ProTaper Next (PTN), X File (XF) y X Gray (XG) mediante microtomografía computarizada (micro-CT). Se dividieron cuarenta y cinco incisivos mandibulares en tres grupos (PTN, XF y XG) con 15 muestras cada uno, de acuerdo con micro-CT preinstrumental (PI). Después de usar cada instrumento, se realizaron nuevos exámenes. Los datos sobre la variación de volumen y las paredes intactas se analizaron mediante la prueba ANOVA de dos factores. y para el primero, se aplicaron en secuencia las pruebas Tukey HSD o Games-Howell. Los datos de transporte y centralización fueron comparados por Kruskal-Wallis y Mann-Whitney. La significación estadística se estableció en $\mathrm{p}<0,05$. Entre los tercios, se encontraron valores de desgaste más altos en la cervical (p $<0,001)$. El PI y el instrumento X3 (30/.07) difirieron en todos los sistemas ( $\mathrm{p}<0.05)$. No hubo diferencia significativa en el porcentaje de paredes intactas entre los sistemas $(\mathrm{p}=0,836)$, mientras que el grado de transporte y centrado fue similar entre ellos, con valores de p de 0,531 y 0,155, respectivamente. Sin embargo, entre tercios se encontró una diferencia significativa $(\mathrm{p}=0,029)$, mostrando el tercio medio mayor centralización que el apical $(\mathrm{p}=0,010)$. En conclusión, PTN, XF y XG obtuvieron resultados similares en la capacidad de modelado, transporte y centralización de canales de ovalados largos.

Palabras clave: Endodoncia; Preparación del conducto radicular; Microtomografía por Rayos X.

\section{Introduction}

Rotating instruments are constantly being developed with a focus on their physical characteristics to improve its performance, such as modeling capacity, resistance to cyclic fatigue, and flexural resistance (Elnaghy, Elsaka, \& Mandorah, 2020). With technological and scientific advances, the root preparations following the original anatomy and direction of the canal, were more easily achieved (Lacerda, Marceliano-Alves, Pérez, Provenzano, Neves, Pires, Gonçalves, Rôças, \& Siqueira Jr, 2017; Peters, 2004). However, there are some dental groups that have certain characteristics that still represent a challenge for the endodontist, such as the lower incisors. Seventy percent of the lower central incisors and 75\% of the lateral incisors have a single canal (type I) (Vertucci, 1984, 2005). A recent study revealed a prevalence of two root canals in the mandibular anterior teeth in Brazilians was approximately $20 \%$ for central and lateral incisors (Candeiro, Monteiro Dodt Teixeira, Olímpio Barbosa, Vivacqua-Gomes, \& Alves, 2021). Also, this dental group has a strong flattening in the mesio-distal direction, which can difficult the endodontic treatment (Schneider, 1971).

The ProTaper Next system (PTN; Dentsply Sirona, Ballaigues, Switzerland) consists of three main instruments X1 (17/.04), X2 (25/.06) and X3 (30/.07) and two complementary X4 (40/.06) and X5 (50/.06), with an asymmetrical rectangular cross-section; they receive a special thermomechanical treatment that provides the nickel-titanium (Ni-Ti) alloy the name MWire, in order to improve flexibility and fatigue strength of the instrument (Elnaghy \& Elsaka, 2014).

The X File (XF) and X Gray (XG) systems (TDK, Shenzhen Superline Technology, Shenzhen, China) are composed by instruments with the same name, tip diameter (D0), and PTN cross-section. According to the manufacturer the differences occur in the variation of the taper throughout the instrument (regressive) and in the received heat treatment Max Tech 3.0 (XF) and Max Tech 9.0 (XG) of the Ni-Ti alloy, which allows an elastic memory in relation to the shape of the instrument. These systems were chosen because despite there are many similarities, there are also important structural differences in relation to PTN system, which could have resulted in different outcomes.

The search for minimally-invasive modalities in endodontics has been highlighted and can be achieved by factors 
such as the reduction of the taper and the anatomical diameter of rotating instruments to preserve the dentinal structure through more conservative wear (Pérez, Alves, \& Marceliano-Alves, 2018); on the other hand, some authors emphasize the importance of the removal of dentin infected by pathogenic bacteria and also to eliminate remaining pulp damaging the conservation of tooth structure (Lacerda et al., 2017). Since the cervical third of the root canal is the most contaminated region, efforts are made to minimize this condition. Thus, cervical preflaring favors the determination of working length (WL) and anatomical diameter, and minimizes accidents (Borges, Damião, Pereira, Filho, Miranda-Pedro, Luiz de Oliveira da Rosa, Piva, \& Guedes, 2018; da Silva, Duarte, Alcalde, Duarte, Vivan, da Rosa, Só, \& do Nascimento, 2020; Plotino, Nagendrababu, Bukiet, Grande, Veettil, De-Deus, \& Aly Ahmed, 2020). Despite being the region that generally suffers the most from the instruments, da Silva et al. (2020), in a study with mandibular incisors, concluded that preflaring and root canal preparation itself reduced dentinal thickness, however, NiTi instruments were not able to change the fracture resistance of these teeth.

Thus, there is always a need to study the performance of rotational systems in terms of volume variation, instrumented areas of root canal, transportation, and centralization. A non-invasive method of analyzing root canal preparation is microcomputed tomography (micro-CT), which allows a three-dimensional reconstruction of extracted teeth (Dowker, Davis, \& Elliott, 1997; Sousa-Neto, Silva-Sousa, Mazzi-Chaves, Carvalho, Barbosa, Versiani, Jacobs, \& Leoni, 2018).

The aim of this study was to analyze the performance of ProTaper Next (PTN), X File (XF) and X Gray (XG) in the shaping ability of long oval-shaped canals, focused on volume variation, untouched walls, transportation, and centralization evaluated by micro-CT. The null hypothesis was that there would be no difference between the systems in the analysis performed.

\section{Methodology}

\subsection{Sample size estimation and characterization}

Using sampling data from previous studies as a reference (De-Deus, Belladonna, Silva, Marins, Souza, Perez, Lopes, Versiani, Paciornik, \& Neves, 2015; Versiani, Carvalho, Mazzi-Chaves, \& Sousa-Neto, 2018; Zuolo, Zaia, Belladonna, Silva, Souza, Versiani, Lopes, \& De-Deus, 2018), the calculation of the power observed in the sample was performed, considering $\alpha$ $=5 \%$ and the rejection of the null hypothesis (existence of a difference between treatments) through the two-way ANOVA test, which resulted in a power value of $99 \%$.

Forty-five extracted human lower incisors, obtained from the University's teeth bank, with a single canal, complete apex, without previous endodontic treatment, calcification, resorption or fracture, and with curvature degree over $8^{\circ}$ for distal direction were selected. The specimens were radiographed in the buccal-lingual and mesio-distal directions with New IDA sensor (Dabi Atlante, Ribeirão Preto, Brazil) and stored in saline solution until the beginning of the study.

The teeth length was standardized at $15 \mathrm{~mm}$. A single operator, an endodontics specialist with five years of experience, performed all stages of the experimental part. The WL was set at $14 \mathrm{~mm}$ by the operator with the verification of the passage of the K 10/.02 manual file (Dentsply Sirona, Ballaigues, Switzerland) through the root apex. All specimens were then subjected to micro-CT (PI).

The Research Ethics Committee approved this study, under register No. 3.837.95, in accordance with the ethical standards of the institutional and/or national research committee and with the 1964 Helsinki declaration and its later amendments or comparable ethical standards.

\subsection{Preparation of specimens}

The specimens were homogeneously divided into three experimental groups $(\mathrm{n}=15)$ according to each system (PTN, $\mathrm{XF}$ or $\mathrm{XG}$ ) based on PI micro-CT analysis. 
In all groups, the instruments $\mathrm{X} 1, \mathrm{X} 2$ and $\mathrm{X} 3$ were used. Each instrument was used to prepare three canals, simulating the use on a molar, and then discarded.

All instruments were used in the X-Smart Plus Endo Motor (Dentsply Sirona, Ballaigues, Switzerland), with $300 \mathrm{rpm}$ speed and $2.0 \mathrm{~N} . \mathrm{cm}$ torque in continue rotation. In the applied kinematics, the instrument was introduced into an apical direction with gentle pressure and brushing movements in the lateral walls of the conduit. After three insertions, the instrument was removed from the canal and cleaned. This process was repeated until the reach of the WL (Pasqualini, Alovisi, Cemenasco, Mancini, Paolino, Bianchi, Roggia, Scotti, \& Berutti, 2015). During the canals instrumentation, irrigation was performed with $3 \mathrm{~mL}$ of $2.5 \%$ sodium hypochlorite, every $2 \mathrm{~mm}$ of advance in the conduit. The NaviTip $27 \mathrm{G}$ needle (Ultradent, South Jordan, Utah, USA) was used constantly in back-and-forth movements, avoiding locking (Haapasalo, Shen, Qian, \& Gao, 2014).

\subsection{Micro-CT and image analysis}

Micro-CT was performed before and after using each instrument in the long oval-shaped canals according to Wu, R'oris, Barkis and Wesselink (2000) method. The digitization was performed on a high-resolution microtomograph (SkyScan 1174, Bruker-microCT, Kontich, Belgium). The scans were taken with image acquisition parameters: $52 \mathrm{kV}, 790 \mu \mathrm{A}$, exposure time approximately 48 minutes, isotropic voxel (pixel size) $19.76 \mu \mathrm{m}, 0.8^{\circ}$ step rotation, $0.5 \mathrm{~mm}$ Al filter. The images were converted to the bpm format. The microtomographic images were reconstructed and processed by the CTAn software (SkyScan, Kontich, Belgium) and overlaid using the DataViewer software (SkyScan, Kontich, Belgium).

The process of rendering the binary phase was done by the CTAn software (SkyScan, Kontich, Belgium), the total volume of the root canal and each third was measured in $\mathrm{mm}^{3}$. The 3D models were reproduced by CTVol software (SkyScan, Kontich, Belgium), and thus it was possible to highlight one binary phase of the other, verifying the images before (PI) and after the procedure with $\mathrm{X} 1, \mathrm{X} 2$, and $\mathrm{X} 3$ of each system in all experimental groups. The percentage of untouched canal walls was assessed with the CTAn software (SkyScan, Kontich, Belgium), by comparing the pre- and post-preparation images (PI and X3).

The method used to analyze the degree of transportation and centralization was based on previous studies (Jatahy Ferreira do Amaral, Leonardi, Gabardo, Coelho, Oliveira, \& Baratto Filho, 2016; Gambill, Alder, \& del Rio, 1996), in which after the overlap, the area of interest along of the WL resulted in 244 sections per sample, so each third had five measurements, approximately $400 \mathrm{~mm}$ apart (16 sections). Then, the mesial pre (m1) and post (m2), distal pre (d1) and post (d2) preparation measures were quantified in millimeters using the CTAn software, and then calculated using the formulas for the degree of transportation: $(\mathrm{m} 1-\mathrm{m} 2)-(\mathrm{d} 1-\mathrm{d} 2)$, and centering: $(\mathrm{m} 1-\mathrm{m} 2) /(\mathrm{d} 1-\mathrm{d} 2)$ or $(\mathrm{d} 1-\mathrm{d} 2) /(\mathrm{m} 1-\mathrm{m} 2)$, when different values were obtained by the two formulas, the lowest result was considered.

The degree of transportation can indicate positive values $(+)$ when the preparation moves to the inner face of the curve (distal), and negative values (-) to the outer face (mesial), while null (0) values demonstrate the non-transportation occurrence. The degree of centralization can obtain values close to zero that indicate decentralization, while 1 corresponds to perfect centralization (Jatahy Ferreira do Amaral et al., 2016).

\subsection{Statistical analysis}

Statistical analyzes were performed using the SPSS program (IBM Corp. Released 2016. IBM SPSS Statistics for Windows, Version 24.0. Armonk, NY: IBM Corp., USA) with a significance level of 0.05. Initially, the data were tested for the Kolmogorov-Smirnov normality test and the Levene variance test. For volume variation, according to system, third, and instrument, the two-way ANOVA test was performed, and multiple comparisons were performed with the Tukey HSD 
(homogeneous variance data) and Games-Howell tests (heterogeneous variance data). For the analysis of untouched walls for the system and third factors, a two-way ANOVA test was performed. For the transportation and centralization variables, according to the system and third, the non-parametric Kruskal-Wallis test was used for general comparisons, and the MannWhitney test for multiple comparisons.

\section{Results}

The volume variation results are presented in Table 1.

Table 1 - Volume variation $\left(\mathrm{mm}^{3}\right)$ according to the system, instrument and third (mean $\left.\pm \mathrm{SD}\right)$.

\begin{tabular}{|c|c|c|c|c|}
\hline \multirow[t]{2}{*}{ System } & \multirow[t]{2}{*}{ Instrument } & \multicolumn{3}{|c|}{ Third } \\
\hline & & Cervical & Middle & Apical \\
\hline \multirow{4}{*}{ PTN } & PI & $12.96 \pm 4.87^{\mathrm{A}, \mathrm{a}}$ & $11.18 \pm 2.87^{\mathrm{A}, \mathrm{b}}$ & $5.31 \pm 1.59^{\mathrm{A}, \mathrm{c}}$ \\
\hline & $\mathrm{X} 1$ & $14.82 \pm 3.70^{\mathrm{AB}, \mathrm{a}}$ & $12.80 \pm 3.13^{\mathrm{AB}, \mathrm{b}}$ & $6.09 \pm 1.74^{\mathrm{AB}, \mathrm{c}}$ \\
\hline & $\mathrm{X} 2$ & $16.48 \pm 3.83^{\mathrm{AB}, \mathrm{a}}$ & $14.08 \pm 2.85^{\mathrm{AB}, \mathrm{b}}$ & $6.81 \pm 1.89^{\mathrm{AB}, \mathrm{c}}$ \\
\hline & $\mathrm{X} 3$ & $19.32 \pm 4.81^{\mathrm{B}, \mathrm{a}}$ & $15.96 \pm 4.17^{\mathrm{B}, \mathrm{b}}$ & $7.47 \pm 1.78^{\mathrm{B}, \mathrm{c}}$ \\
\hline \multirow{4}{*}{$\mathrm{XF}$} & PI & $13.89 \pm 4.04^{\mathrm{A}, \mathrm{a}}$ & $13.48 \pm 3.55^{\mathrm{A}, \mathrm{b}}$ & $6.22 \pm 2.57^{\mathrm{A}, \mathrm{c}}$ \\
\hline & $\mathrm{X} 1$ & $15.50 \pm 4.44^{\mathrm{AB}, \mathrm{a}}$ & $14.32 \pm 3.90^{\mathrm{AB}, \mathrm{b}}$ & $6.83 \pm 2.58^{\mathrm{AB}, \mathrm{c}}$ \\
\hline & $\mathrm{X} 2$ & $16.83 \pm 4.61^{\mathrm{AB}, \mathrm{a}}$ & $15.26 \pm 4.05^{\mathrm{AB}, \mathrm{b}}$ & $7.40 \pm 2.50^{\mathrm{AB}, \mathrm{c}}$ \\
\hline & $\mathrm{X} 3$ & $19.11 \pm 4.90^{\mathrm{B}, \mathrm{a}}$ & $17.24 \pm 3.99^{\mathrm{B}, \mathrm{b}}$ & $8.50 \pm 2.52^{\mathrm{B}, \mathrm{c}}$ \\
\hline \multirow{4}{*}{$X G$} & PI & $14.13 \pm 4.25^{\mathrm{A}, \mathrm{a}}$ & $12.31 \pm 3.22^{\mathrm{A}, \mathrm{b}}$ & $5.89 \pm 1.30^{\mathrm{A}, \mathrm{c}}$ \\
\hline & $\mathrm{X} 1$ & $17.17 \pm 3.82^{\mathrm{AB}, \mathrm{a}}$ & $13.90 \pm 2.54^{\mathrm{AB}, \mathrm{b}}$ & $6.66 \pm 1.34^{\mathrm{AB}, \mathrm{c}}$ \\
\hline & $\mathrm{X} 2$ & $18.33 \pm 3.96^{\mathrm{AB}, \mathrm{a}}$ & $15.10 \pm 3.06^{\mathrm{AB}, \mathrm{b}}$ & $7.12 \pm 1.28^{\mathrm{AB}, \mathrm{c}}$ \\
\hline & $\mathrm{X} 3$ & $20.46 \pm 4.57^{\mathrm{B}, \mathrm{a}}$ & $16.18 \pm 2.84^{\mathrm{B}, \mathrm{b}}$ & $7.85 \pm 1.76^{\mathrm{B}, \mathrm{c}}$ \\
\hline
\end{tabular}

SD, standard deviation; PTN, ProTaper Next; XF, X File; XG, X Gray; PI, pre-instrumentation value.

Different capital letters indicate statistically significant differences in the column. Lower case letters indicate statistically significant differences in the line.

Source: Authors.

A significant difference among the thirds was found, the cervical showed a higher value than the middle $(p<0.001)$, and both cervical and middle thirds volume values were higher than the apical ( $\mathrm{p}<0.001)$; however, there was no significant difference when compared the three studied systems ( $\mathrm{p}>0.05)$.

The analysis of the untouched walls is reported in Table 2.

Table 2 - Variation of the percentage of untouched area according to the system (mean \pm SD).

\begin{tabular}{lccccc}
\hline System & \multicolumn{5}{c}{ Non-instrumented area (\%) } \\
\cline { 2 - 6 } & Mean \pm SD & $\begin{array}{c}\text { Lower } \\
\text { Limit }\end{array}$ & $\begin{array}{c}\text { Upper } \\
\text { limit }\end{array}$ & Minimum & Maximum \\
\hline PTN & $37.41 \pm 11.34^{\mathrm{A}}$ & 31.13 & 43.69 & 22.73 & 57.27 \\
XF & $40.05 \pm 13.11^{\mathrm{A}}$ & 32.79 & 47.31 & 19.98 & 60.71 \\
XG & $38.71 \pm 11.67^{\mathrm{A}}$ & 32.25 & 45.17 & 18.46 & 54.05 \\
\hline
\end{tabular}

SD, standard deviation; PTN, Protaper Next; XF, X File; XG, X Gray. Source: Authors.

Untouched walls data showed similar percentage measures according to the systems $(p=0.836)$.

The degree of transportation is presented in Table 3 and centralization data are reported in Table 4. 
Table 3 - Percentage differences (pre- and post-preparation) in the transportation according to the system and third (mean \pm $\mathrm{SD})$.

\begin{tabular}{lccc}
\hline & & Third & \\
\cline { 2 - 4 } System & Cervical & Middle & Apical \\
\hline PTN & $5.76 \pm 22.72^{\mathrm{Aa}}$ & $7.04 \pm 15.68^{\mathrm{Ba}}$ & $2.64 \pm 13.39^{\mathrm{Ca}}$ \\
XF & $6.96 \pm 15.19^{\mathrm{Ab}}$ & $6.80 \pm 14.50^{\mathrm{Bb}}$ & $1.36 \pm 13.15^{\mathrm{Cb}}$ \\
XG & $6.83 \pm 8.89^{\mathrm{Ac}}$ & $5.63 \pm 12.03^{\mathrm{Bc}}$ & $1.67 \pm 15.76^{\mathrm{Cc}}$ \\
\hline
\end{tabular}

SD, standard deviation; PTN, ProTaper Next; XF, X File; XG, X Gray; PI, pre-instrumentation value. Different capital letters indicate statistically significant differences in the column. Lower case letters indicate statistically significant differences in the line.

Source: Authors.

Table 4 - Differences (pre- and post-preparation) in the centralization according to the system and third (mean \pm SD).

\begin{tabular}{lccc}
\hline & & Third & Apical \\
\cline { 2 - 4 } System & Cervical & Middle & $0.62 \pm 0.26^{\mathrm{Cb}}$ \\
\hline PTN & $0.71 \pm 0.17^{\mathrm{Aa}}$ & $0.73 \pm 0.19^{\mathrm{Ba}}$ & $0.52 \pm 0.29^{\mathrm{Cb}}$ \\
XF & $0.67 \pm 0.27^{\mathrm{Aa}}$ & $0,72 \pm 0.21^{\mathrm{Ba}}$ & $0.55 \pm 0.26^{\mathrm{Cb}}$ \\
XG & $0.70 \pm 0.22^{\mathrm{Aa}}$ & $0.65 \pm 0.26^{\mathrm{Ba}}$ & 0.00 \\
\hline
\end{tabular}

SD, standard deviation; PTN, ProTaper Next; XF, X File; XG, X Gray; PI, pre-instrumentation value. Different capital letters indicate statistically significant differences in the column. Lower case letters indicate statistically significant differences in the line. Source: Authors.

The transportation degree was similar according to the systems $(\mathrm{p}=0.531)$ and thirds evaluated $(\mathrm{p}=0.176)($ Table 3$)$. The centralization was similar between the systems $(\mathrm{p}=0.155)$, but indicated a significant difference between the thirds $(\mathrm{p}=$ 0.029), in which the middle third presented greater centralization than the apical ( $\mathrm{p}=0.010)$, and was similar to the cervical ( $\mathrm{p}$ $=0.061)$; the cervical and middle thirds also showed no differences $(p=0.484)$ (Table 4$)$.

The superimposition of microtomographic pre and post-preparation images is observable in Figure 1. 
Figure 1 - Pre- and post-preparation microtomographic images and their superposition of the systems PTN (A, B, C), XF (D, E, F), and XG (G, H, I), respectively.

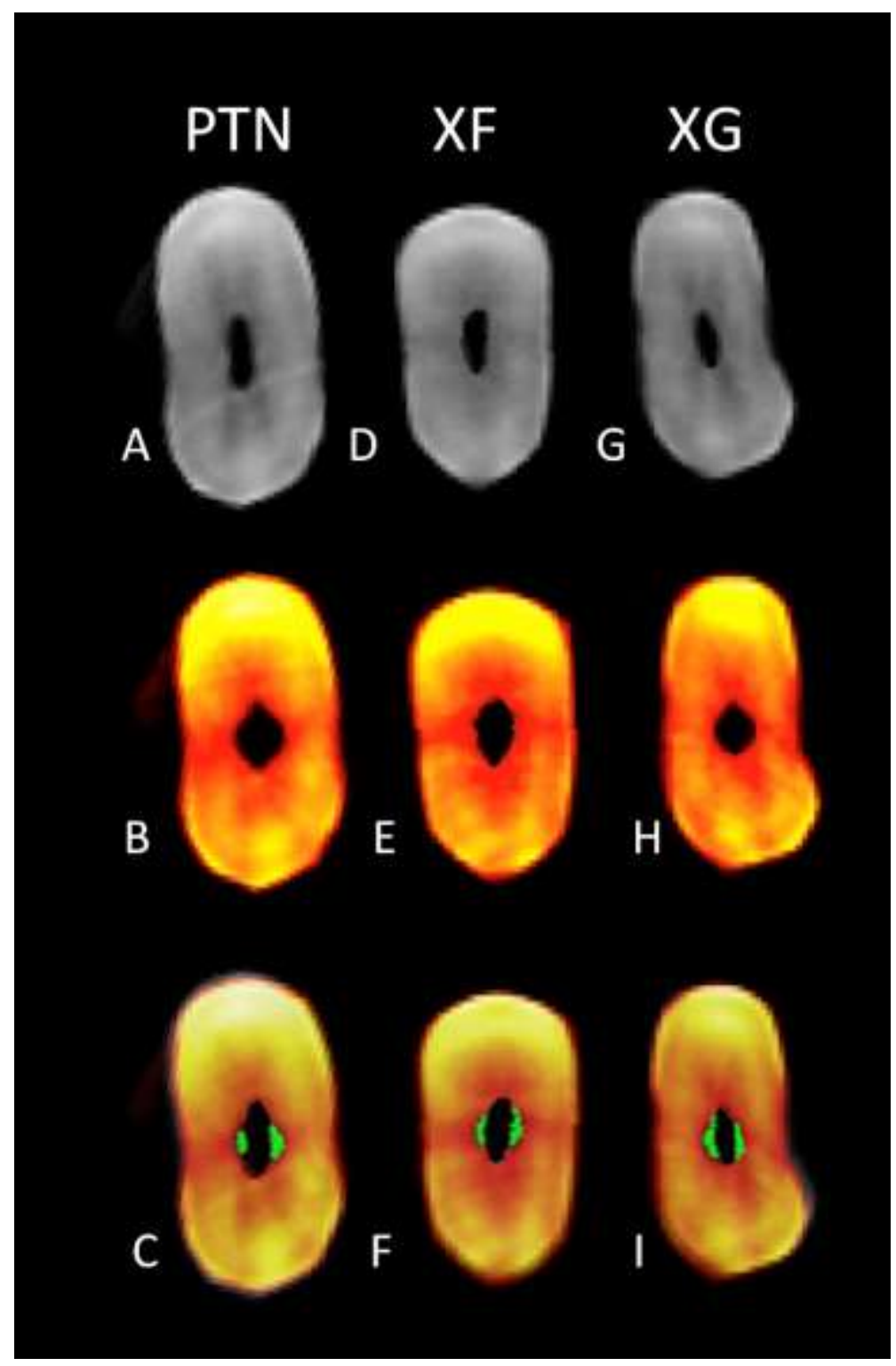

Source: Authors.

\section{Discussion}

The aim of this study was to compare the performance of PTN, XF and XG systems, according to analysis of the volume variation, percentage of untouched root canal walls, transportation, and centralization. The null hypothesis was accepted in all contexts.

The anatomical complexity of the root canal system can represent a challenge in endodontic treatment (Vertucci, 1984, 2005), highlighting the lower incisors, which have a peculiar morphology, with a prevalence of $20 \%$ of two root canals (Candeiro et al., 2021), not straight and with a flattening in the mesio-distal direction (Schneider, 1971), the reasons why these teeth were chosen for this research. According to Schneider (1971) teeth are considered straight when its curvature degree is equal or less than $5^{\circ}$. Most of lower incisors present straight root, despite there are also roots curved in direction to vestibular or distal (Sousa-Neto et al., 2018). The 45 selected teeth presented degree of curvature over $8^{\circ}$ directed to distal side of the root. To homogenize the dental groups, the classification by Wu et al. (2000) was chosen for selecting the long oval-shaped 
canals, based on PI micro-CT exams.

Clinically, the presence of some degree of curvature makes endodontic treatment difficult, mainly due to the possibility of deviations in relation to the main axis (Abou-Rass, Frank, \& Glick, 1980). Additionaly, the flattening of the oval canals causes a need for great dentin removal during preparation (Silva, Muniz, Pires, Pires, Belladonna, Neves, Souza, \& DeDeus, 2016).

The systems studied exhibit some similar characteristics, such as D0 and nomenclature of the instruments [X1 (17/.04), X2 (25/.06), and X3 (30/.07)], asymmetric rectangular cross-section, the absence of radial bands, and non-cutting tip; however, there are important differences, such as heat treatment and taper. PTN receives a treatment that names it as M-Wire. According to the manufacturer, the distinctions between the XF and XG systems in relation to PTN are intended to improve their elastic memory, facilitating the action in canals with curvature, preserving the preparation on the opposite side to the curvature, in addition to promoting more endodontic preparation. conservative, respecting the anatomy of the canal, to avoid severe wear that weakens the tooth structure and increases the risk of fracture (Pinheiro, Alcalde, Vivacqua-Gomes, Bramante, Vivan, Duarte, \& Vasconcelos, 2018).

In this research, in order to reproduce the clinical reality, each instrument was used to prepare three canals, which would correspond clinically to the preparation of a molar. In these circumstances, there was no fracture of any instrument, which is an important concern in the root canal shaping (Elnaghy \& Elsaka, 2014).

Micro-CT was applied due to its non-destructive property, since it does not damage the dental structure, additionally, the images are superior in quality when compared to radiographs, mainly because of the deep structures evaluation possibility, which becomes the analysis more effective since the three-dimensional aspect of dental samples is considered (Dowker et al., 1997; Pasqualini et al., 2015). This examination allows a quantitative evaluation of volume, surface area, and structure model index (SMI), in addition to the two-dimensional area verification, perimeter, diameter, and canal shape, thus the dental morphology evaluation enables more reliable results (Sousa-Neto et al., 2018).

The findings regarding of the volume variation demonstrated no difference in the effectiveness of dentin wear among the systems, despite the regressive taper of the XF and XG, it can be concluded that this factor was not decisive in determining the final volume, probably due to the predominant similarities between the instruments previous mentioned. The highest volume value after preparation (X3) in relation to the initial (PI) was predicted, mainly considering that one of the objectives of endodontic therapy is the removal of infected dentin for clinical success, which is in agreement with other studies (Elnaghy \& Elsaka, 2014; Pasqualini et al., 2015; Thomas, Lynch, Paurazas, \& Askar, 2020). A significant difference between the thirds was also expected due to their anatomical particularities, since the cervical third have higher volume than the middle which in turn presents higher volume than the apical. In addition, the preparation tends to preserve the original root canals anatomy (Vertucci, 2005). Also, the preflaring is a fundamental step in the treatment, as in addition to removing the most infected dentin portion, it favors the establishment of the WL and the anatomical diameter (Borges et al., 2018; da Silva et al., 2020; Plotino et al., 2020), factors that better adjust the file in the apical region (Barroso, Guerisoli, Capelli, Saquy, \& Pécora, 2005).

The preparation of mandibular incisors up to the instrument \#30 is found in the literature. Khademi, Yazdizadeh, and Feizianfard (2006) postulated that if cervical third preparation is adequate, it is not necessary an enlargement superior than \#30. The authors consider this values the minimum needed for penetration of irrigants to the apical third of the root canal, while Ribeiro, Silva-Sousa, Souza-Gabriel, Sousa-Neto, Lorencetti, and Silva, confirmed that a cervical flaring and preparation of canals up to instrument 35/.02, produced divergent walls that permitted an adequate irrigation.

The analysis of untouched walls also did not indicate any distinction in relation to the systems, which, added to the results of the volume variation, suggests that the larger taper is not a determining factor for the preparation of larger areas (Paqué, Ganahl, \& Peters, 2009). Clinically, this analysis is essential to avoid the spread of residual bacteria that could lead to 
treatment failure (De-Deus et al., 2015). The average values obtained by this analysis (37.41\%) are similar to those reported in the study by Drukteinis, Peciuliene, Dummer and Hupp (2019) who evaluated the PTN system (X3) in the mesial canals of the lower molars (40.84\%). Zhao, Shen, Peng and Haapasalo (2014) also verified the PTN system action (X2 in the mesials and $\mathrm{X} 4$ in the distal) in mandibular molars and reported the percentages of untouched walls in the mesio-buccal (41.5\%), mesiolingual (36.9\%), and distal (55.3\%) canals.

Transportation is an undesirable deviation from the original canal path that can occur during preparation. Clinically, it can impair treatment longevity by favoring the maintenance of non-instrumented areas, which can lead to persistent periapical lesions (Peters, 2004). The method developed by Gambill et al. (1996) was used to verify that, although all systems present some degree of transportation, XF and XG were more conservative than PTN. Despite this, they are all within the acceptable value, which ranges from 0.15 to $0.3 \mathrm{~mm}$ in the literature records, in order not to harm the disinfection and the correct sealing of the apical region, therefore PTN, XF and XG are considered safe (Mamede-Neto, Borges, Guedes, de Oliveira, Pedro, \& Estrela, 2017; Peters, 2004). It can be hypothesized that there is some relationship between the heat treatment given to the instruments and the results found here.

In curved canals, the tendency is for the transportation to take place in the opposite direction to the curvature (mesial), because the distal wall pushes the instrument in the opposite direction, so this process is intensified according to the increase in the instrument's taper (Gergi, Osta, Bourbouze, Zgheib, Arbab-Chirani, \& Naaman, 2015), which justifies the results found, since PTN does not present regressive taper like other systems, although it is necessary to determine the clinical implications of the magnitude of apical transportation (Mamede-Neto et al., 2017).

As in the present study, most findings in the literature do not show differences between the systems studied regarding the degree of transportation (Bürklein, Hinschitza, Dammaschke, \& Schäfer, 2012; Capar, Ertas, Ok, Arslan, \& Ertas, 2014; Silva, et al., 2016). According to Mamede-Neto et al. (2017), the PTN system did not show a trend of transportation to the mesial direction in mandibular premolars, which is corroborated by other studies that indicate that NiTi instruments can produce low linear transportation at values (Bürklein et al., 2012; Silva et al., 2016).

Centralization is important to prevent the occurrence of transportation, perforations, and weakening of the tooth remnant, and in this study none of the instruments presented perfect centralization, which is in agreement with other reports (Jatahy Ferreira do Amaral et al., 2016; Mamede-Neto et al., 2017; Pinheiro et al., 2018). The degree of centralization is favored by the instrument's non-cutting tip, which facilitates its penetration with little apical pressure (Mamede-Neto et al., 2017; Silva et al., 2016; Pinheiro et al., 2018).

As in this study, Jatahy Ferreira do Amaral et al. (2016) also reported that the best centering occurred in the middle third, although the study was carried out with upper molars, with a degree of curvature from $10^{\circ}$ to $20^{\circ}$, values similar to what is presented here, therefore, this result seems to be related to the action of the instruments as a function of the curved anatomy of these canals.

Based on the results found here, clinical relevance refers to the possibility of knowing the performance of different systems, which expands the possibility of choice and use. It should be emphasized that the similarity concerning the instrument performance may have been favored, in a way, by the anatomical aspects of the analyzed teeth, with a single canal and without expressive curvature, which characterizes a limitation, as well as those relevant to in vitro studies. In addition to the capacity of the dentin wear, the analysis of deformation of instruments, fracture resistance, flexural resistance, heat treatments, use in canals with accentuated curvature, among others, must be considered as important topics for future studies.

\section{Conclusion}

Despite the limitations of this study, the PTN, XF and XG systems obtained similar results regarding the shaping 
ability of long oval-shaped canals.

\section{References}

Abou-Rass, M., Frank, A. L., \& Glick, D. H. (1980). The anticurvature filing method to prepare the curved root canal. Journal of the American Dental Association, 101(5), 792-794.

Barroso, J. M., Guerisoli, D. M. Z., Capelii, A., Saquy, P. C., \& Pécora, J. D. (2005). Influence of cervical preflaring on determination of apical file size in maxillary premolars: SEM analysis. Brazilian Dental Journal, 16(1): 30-34.

Borges, A. H., Damião, M. S., Pereira, T. M., Filho, G. S., Miranda-Pedro, F. L., Luiz de Oliveira da Rosa, W., Piva, E., \& Guedes, O. A. (2018). Influence of cervical preflaring on the incidence of root dentin defects. Journal of Endodontics, 44(2), 286-291.

Bürklein, S., Hinschitza, K., Dammaschke, T., \& Schäfer, E. (2012). Shaping ability and cleaning effectiveness of two single-file systems in severely curved root canals of extracted teeth: Reciproc and WaveOne versus Mtwo and ProTaper. International Endodontic Journal, 45(5), 449-61.

Candeiro, G., Monteiro Dodt Teixeira, I.M., Olimpio Barbosa, D.A., Vivacqua-Gomes, N., \& Alves, F. (2021). Vertucci's root canal configuration of 14,413 mandibular anterior teeth in a Brazilian population: A prevalence study using cone-beam computed tomography. Journal of Endodontics, 47(3), 404-408.

Capar, I. D., Ertas, H., Ok, E., Arslan, H., \& Ertas, E. T. (2014). Comparative study of different novel nickel-titanium rotary systems for root canal preparation in severely curved root canals. Journal of Endodontics, 40(6), 852-856.

da Silva, P. B., Duarte, S. F., Alcalde, M. P., Duarte, M., Vivan, R. R., da Rosa, R. A., Só, M., \& do Nascimento, A. L. (2020). Influence of cervical preflaring and root canal preparation on the fracture resistance of endodontically treated teeth. BMC Oral Health, $20(1), 111$.

De-Deus, G., Belladonna, F. G., Silva, E. J., Marins, J. R., Souza, E. M., Perez, R., Lopes R. T., Versiani, M. A., Paciornik, S., \& Neves Ade, A. (2015). Micro-CT Evaluation of non-instrumented canal areas with different enlargements performed by NiTi systems. Brazilian Dental Journal, 26(6), 624-629.

Dowker, S. E. P., Davis, G. R., \& Elliott, J. C. (1997). X-ray microtomography: Nondestructive three-dimensional imaging for in vitro endodontic Studies. Oral Surgery, Oral Medicine, Oral Pathology, Oral Radiology and Endodontics, 83(4), 510-516.

Drukteinis, S., Peciuliene, V., Dummer, P. M. H., \& Hupp, J. (2019). Shaping ability of BioRace, ProTaper NEXT and Genius nickel-titanium instruments in curved canals of mandibular molars: A microCT study. International Endodontic Journal, 52(1), 86-93.

Elnaghy, A. M., \& Elsaka, S. E. (2014). Evaluation of root canal transportation, centering ratio, and remaining dentin thickness associated with ProTaper Next instruments with and without glide path. Journal of Endodontics, 40(12), 2053-2056.

Elnaghy, A. M., Elsaka, S. E., \& Mandorah, A.O. (2020). In vitro comparison of cyclic fatigue resistance of TruNatomy in single and double curvature canals compared with different nickel-titanium rotary instruments. BMC Oral Health, 20(1), 38-45.

Gambill, J. M., Alder, M., \& del Rio, C. E. (1996). Comparison of nickel-titanium and stainless steel hand-file instrumentation using computed tomography. Journal of Endodontics, 22(7), 369-375.

Gergi, R., Osta, N., Bourbouze, G., Zgheib, C., Arbab-Chirani, R., \& Naaman, A. (2015). Effects of three nickel titanium instrument systems on root canal geometry assessed by micro-computed tomography. International Endodontic Journal, 48(2), 162-170.

Haapasalo, M., Shen, Y., Qian, W., \& Gao, Y. (2014). Irrigation in endodontics. Brazilian Dental Journal, $216(6), 299-303$.

Jatahy Ferreira do Amaral, R. O., Leonardi, D. P., Gabardo, M. C., Coelho, B. S., Oliveira, K. V., \& Baratto Filho, F. (2016). Influence of cervical and apical enlargement associated with the WaveOne system on the transportation and centralization of endodontic preparations. Journal of Endodontics, 42(4), 626-631.

Khademi, A., Yazdizadeh, M., \& Feizianfard, M. (2006). Determination of the minimum instrumentation size for penetration of irrigants to the apical third of root canal systems. Journal of Endodontics, 32(5), 417-420.

Lacerda, M. F. L. S., Marceliano-Alves, M. F., Pérez, A. R., Provenzano, J. C., Neves, M. A. S., Pires, F. R., Gonçalves, L. S., Rôças, I. N., \& Siqueira, J. F. Jr. (2017). Cleaning and shaping oval canals with 3 instrumentation systems: A correlative micro-computed tomographic and histologic study. Journal of Endodontics, 43(11), 1878-1884.

Mamede-Neto, I., Borges, A. H., Guedes, O. A., de Oliveira, D., Pedro, F. L., \& Estrela, C. (2017). Root canal transportation and centering ability of nickeltitanium rotary instruments in mandibular premolars assessed using cone-beam computed tomography. Open Dentistry Journal, 11, 71-78.

Paqué, F., Ganahl, D., \& Peters, O. A. (2009). Effects of root canal preparation on apical geometry assessed by micro-computed tomography. Journal of Endodontics, 35(7), 1056-1059.

Pasqualini, D., Alovisi, M., Cemenasco, A., Mancini, L., Paolino, D. S., Bianchi, C. C., Roggia, A., Scotti, N., \& Berutti, E. (2015). Micro-computed tomography evaluation of ProTaper Next and BioRace shaping outcomes in maxillary first molar curved canals. Journal of Endodontics, 41(10), 1706-1710.

Pérez, A. R., Alves, F. R. F., \& Marceliano-Alves, M. F. (2018). Effects of increased apical enlargement on the amount of unprepared areas and coronal dentine removal: a micro-computed tomography study. International Endodontic Journal, 51(6), 684-690.

Peters, O. A. (2004). Current challenges and concepts in the preparation of root canal systems: a review. Journal of Endodontics, $30(8), 559-567$.

Pinheiro, S. R., Alcalde, M. P., Vivacqua-Gomes, N., Bramante, C. M., Vivan, R. R., Duarte, M. A. H., \& Vasconcelos, B.C. (2018). Evaluation of apical transportation and centring ability of five thermally treated NiTi rotary systems. International Endodontic Journal, 51(6), 705-713. 
Research, Society and Development, v. 10, n. 11, e349101119593, 2021

(CC BY 4.0) | ISSN 2525-3409 | DOI: http://dx.doi.org/10.33448/rsd-v10i11.19593

Plotino, G., Nagendrababu, V., Bukiet, F., Grande, N. M., Veettil, S. K., De-Deus, G., \& Aly Ahmed, H. M. (2020). Influence of negotiation, glide path, and preflaring procedures on root canal shaping-terminology, basic concepts, and a systematic review. Journal of Endodontics, 46(6), 707-729.

Ribeiro, E. M., Silva-Sousa, Y. T., Souza-Gabriel, A. E., Sousa-Neto, M. D., Lorencetti, K. T., \& Silva, S. R. (2012). Debris and smear removal in flattened root canals after use of different irrigant agitation protocols. Microscopy Research and Technique, 75(6), 781-790.

Schneider, S. W. (1971). A comparison of canal preparations in straight and curved root canals. Oral Surgery, Oral Medicine and Oral Pathology, 32(2), 271275 .

Silva, E. J. N. L., Muniz, B. L., Pires, F., Pires, F., Belladonna, F. G., Neves, A. A., Souza, E. M., \& De-Deus, G. (2016). Comparison of canal transportation in simulated curved canals prepared with ProTaper Universal and ProTaper Gold systems. Restorative Dentistry \& Endodontics, 41(1), 1-5.

Sousa-Neto, M. D., Silva-Sousa, Y. C., Mazzi-Chaves, J. F., Carvalho, K. K. T., Barbosa, A. F. S., Versiani, M. A., , Jacobs, R., \& Leoni, G.B. (2018). Root canal preparation using micro-computed tomography analysis: a literature review. Brazilian Oral Research, 32(suppl.1), 20-43.

Thomas, J. P., Lynch, M., Paurazas, S., \& Askar, M. (2020). Micro-computed tomographic evaluation of the shaping ability of WaveOne Gold, TRUShape, EdgeCoil, and XP-3D shaper endodontic files in single, oval-shaped canals: An in vitro study. Journal of Endodontics, 46(2), 244-251.

Versiani, M. A., Carvalho, K. K. T., Mazzi-Chaves, J. F., \& Sousa-Neto, M. D. (2018). Micro-computed tomographic evaluation of the shaping ability of XPendo Shaper, iRaCe, and EdgeFile systems in long oval-shaped canals. Journal of Endodontics, 44(3), 489-495.

Vertucci, F. J. (1984). Root canal anatomy of the human permanent teeth. Oral Surgery, Oral Medicine and Oral Pathology, 58(5), 589-599.

Vertucci, F. J. (2005). Root canal morphology and its relationship to endodontic procedures. Endodontic Topics, 10(1), 3-29.

Wu, M. K., R'oris, A., Barkis, D., \& Wesselink, P. R. (2000). Prevalence and extent of long oval canals in the apical third. Oral Surgery, Oral Medicine, Oral Pathology, Oral Radiology and Endodontics, 89(6), 739-743.

Zhao, D., Shen, Y., Peng, B., \& Haapasalo, M. (2014). Root canal preparation of mandibular molars with 3 nickel-titanium rotary instruments: A microcomputed tomographic study. Journal of Endodontics, 40(11), 1860-1864.

Zuolo, M. L., Zaia, A. A., Belladonna, F. G., Silva, E. J. N. L., Souza, E. M., Versiani, M. A., Lopes, R. T., De-Deus, G. (2018). Micro-CT assessment of the shaping ability of four root canal instrumentation systems in oval-shaped canals. International Endodontic Journal, 51(5), 564-571. 